\title{
Comatulins A-E, Taurine-Conjugated Anthraquinones from the Australian Crinoid Comatula rotalaria
}

Kah Yean Lum,,$^{\dagger}$ Aya C. Taki,,$^{\star}$ Robin B. Gasser,,$^{\star}$ Ian Tietjen,,$^{\xi \wedge}$ Merrick G. Ekins, $\|,{ }^{\dagger}$ Jonathan M. White, ${ }^{\nabla}$ Russell S. Addison, ${ }^{\dagger}$ Sasha Hayes, ${ }^{\dagger}$ James St John, ${ }^{\dagger}, O$ Rohan A. Davis ${ }^{*}{ }^{\dagger}$

${ }^{\dagger}$ Griffith Institute for Drug Discovery, Griffith University, Brisbane, QLD 4111, Australia

Department of Biosciences, Melbourne Veterinary School, Faculty of Veterinary and Agricultural Sciences, The University of Melbourne, Parkville, VIC 3010, Australia

${ }^{\S}$ Faculty of Health Sciences, Simon Fraser University, Burnaby, BC, Canada

`The Wistar Institute, Philadelphia, PA, USA

"Biodiversity and Geosciences, Queensland Museum, South Brisbane BC, QLD 4101, Australia

${ }^{\nabla}$ School of Chemistry and Bio21 Institute, The University of Melbourne, Melbourne, VIC 3010, Australia

${ }^{\text {O }}$ Menzies Health Institute Queensland, Griffith University, Southport, 4222, QLD, Australia 


\begin{abstract}
Chemical investigations of two specimens of the Australian crinoid Comatula rotalaria afforded five new taurine-conjugated anthraquinones, comatulins A-E (1-5), together with 11 known marine natural products $\left(6^{-16}\right)$. The chemical structures of all of the compounds were elucidated by detailed spectroscopic and spectrometric data analysis. The first X-ray crystal structure of a crinoid-derived acyl anthraquinone, rhodocomatulin 5,7-dimethyl ether (8), is reported here. Compounds $\mathbf{1}, \mathbf{2}, \mathbf{6}-\mathbf{1 3}$, and two additional naphthopyrone derivatives $\mathbf{1 7}-\mathbf{1 8}$ were evaluated for their ability to inhibit HIV-1 replication in vitro; none of the compounds were active at $100 \mu \mathrm{M}$. Furthermore, compounds $\mathbf{1 , ~ 2 , ~ 6 - 1 0 , ~ 1 4 - 1 5 , ~ 1 7 - 1 8 ~ w e r e ~ s c r e e n e d ~ f o r ~ n e m a t o c i d a l ~}$ activity against exsheathed third-stage larvae of Haemonchus contortus, a highly pathogenic parasite nematode of ruminants. Compound $\mathbf{1 7}$, known as 6-methoxycomaparvin 5,8-dimethyl ether showed an inhibitory effect on larval motility $\left(\mathrm{IC}_{50}=30 \mu \mathrm{M}\right)$ and development $\left(\mathrm{IC}_{50}=31\right.$ $\mu \mathrm{M})$ and induced the eviscerated (Evi) phenotype.
\end{abstract}


Crinoids are known to produce diverse polyketide-derived pigments such as anthraquinones, naphthopyrones, bisanthrones, and phenanthroperylenequinones. ${ }^{1}$ These pigments are not only responsible for the colorful appearance of crinoids, but are also used as chemical defense against predatory fish. ${ }^{2,3}$ Some of these metabolites also exhibit in vitro activities in a range of biomedical assays. For instance, the brominated phenanthroperylenequinones, gymnochrome D and isogymnochrome D, isolated from the deep-water stalked crinoid Gymnocrinus richeri, inhibit dengue virus at doses of $<0.89 \mathrm{nM}{ }^{4,5}$ The comatulid-derived anthraquinone, (+)-rhodoptilometrin has been reported to promote tissue regeneration by increasing wound healing and cell migration of human gingival fibroblasts at 1 and $10 \mu \mathrm{M}$, respectively. ${ }^{6}$ Our recent investigations of the chemistry of the feather star, Capillaster multiradiatus, revealed an inhibitory activity of the angular naphthopyrone comaparvin, by blocking in vitro HIV-1 replication with an $\mathrm{EC}_{50}$ of 7.5 $\mu \mathrm{M} .^{7}$

Although numerous compounds have been isolated from crinoids, only two chemical studies have been reported on Comatula rotalaria to date. Chemical investigations of C. rotalaria (Lamarck), collected from Western Australian waters, were first reported in 1980 by Francesconi and yielded two known 1-acylanthraquinone derivatives, including rhodocomatulin 7-methyl ether (6) and rhodocomatulin 5,7-dimethyl ether $(\mathbf{8}){ }^{8}{ }^{8}$ Studies of the same species collected from the Torres Strait (Northern Australia) led to the isolation of compounds $\mathbf{6}$ and $\mathbf{8}$, together with two new derivatives, 12-desethylrhodocomatulin 7-methyl ether (7) and 12-desethylrhodocomatulin 5,7-dimethyl ether (9). ${ }^{9}$ As only four acyl-derivatives of anthraquinones were identified in this species, we elected to explore a further two C. rotalaria specimens collected from different locations on the Great Barrier Reef for new chemistry. These specimens were obtained from the biota repository of Griffith University's NatureBank, ${ }^{10}$ which currently curates a range of marine 
invertebrates ( $>10,000$ samples) collected from Australian waters. Analysis of the C. rotalaria extracts by UHPLC-MS, in conjunction with database searching, suggested the presence of three new anthraquinones (Supporting Information S1 for UHPLC-MS data). Here, we describe the isolation and structure elucidation of a series of new taurine-conjugated anthraquinones from these two Australian C. rotalaria specimens, to which we have given the trivial names, comatulins AE. We also report the anti-HIV-1 replication activity and anthelmintic activity of subsets of these compounds.

\section{RESULTS AND DISCUSSION}

Two freeze-dried and ground specimens of C. rotalaria (SBD517512 and SBD522143) were exhaustively extracted with $\mathrm{CH}_{2} \mathrm{Cl}_{2}, \mathrm{MeOH}, \mathrm{MeOH} / \mathrm{H}_{2} \mathrm{O}(1: 1)$ and $\mathrm{MeOH} / \mathrm{H}_{2} \mathrm{O}(1: 9)$. The extracts of the two crinoid specimens were analyzed using UHPLC-MS. Following the data analysis, $\mathrm{MeOH} / \mathrm{H}_{2} \mathrm{O}$ (1:9) extracts were devoid of natural products and thus no further purification was undertaken. For the first specimen of C. rotalaria (SBD517512), the $\mathrm{MeOH}$ extract was resuspended in $\mathrm{H}_{2} \mathrm{O}$ and extracted sequentially with EtOAc then $n$-BuOH. Purification of the $n$ $\mathrm{BuOH}$-soluble material by reversed-phase HPLC (RP-HPLC) led to the isolation of four new metabolites, comatulins A-D (1-4). The $\mathrm{MeOH} / \mathrm{H}_{2} \mathrm{O}(1: 1)$ extract was also fractionated using RPHPLC to yield further quantities of compounds $\mathbf{1}$ and 2. The $\mathrm{CH}_{2} \mathrm{Cl}_{2}$ extract and EtOAc-soluble material (from the $\mathrm{MeOH}$ extract partition) were separately subjected to extensive normal-phase or reversed-phase chromatography to yield eight known anthraquinones, including rhodocomatulin 7-methyl ether (6), 12-desethylrhodocomatulin 7-methyl ether (7),

rhodocomatulin 5,7-dimethyl ether (8), 12-desethylrhodocomatulin 5,7-dimethyl ether (9), rhodocomatulin (10), rhodolamprometrin (11), 6-methoxyrhodocomatulin 7-methyl ether (12), 
and rheoemodin (13). ${ }^{9,11,12}$ Chemical investigations of the other specimen of $C$. rotalaria (SBD522143) was performed using the same extraction and chromatographic methods as described above. Further quantities of compounds $\mathbf{1}$ and 2, together with a new metabolite comatulin $\mathrm{E}$ (5), were isolated from the $n$ - $\mathrm{BuOH}$-soluble material of the $\mathrm{MeOH}$ extract. Purification of the $\mathrm{CH}_{2} \mathrm{Cl}_{2}$ extract resulted in the isolation of three additional known naphthopyrones, including 6-methoxycomaparvin (14), 6-methoxycomaparvin 5-methyl ether (15), and 5,8-dihydroxy-6,10-dimethoxy-2-methyl-4H-benzo[h]chromen-4-one Comatulin A-E (1-5) were all characterized as their trifluoroacetate salts.

\section{Chart 1}

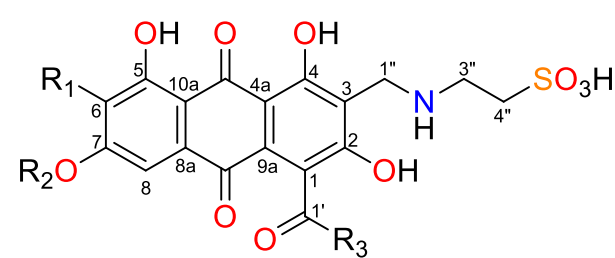

$1 \mathrm{R}_{1}=\mathrm{H}, \mathrm{R}_{2}=\mathrm{Me}, \mathrm{R}_{3}=\mathrm{Me}$

$2 \mathrm{R}_{1}=\mathrm{H}, \mathrm{R}_{2}=\mathrm{Me}, \mathrm{R}_{3}=\mathrm{Pr}$

$3 \mathrm{R}_{1}=\mathrm{R}_{2}=\mathrm{H}, \mathrm{R}_{3}=\mathrm{Me}$

$4 \mathrm{R}_{1}=\mathrm{R}_{2}=\mathrm{H}, \mathrm{R}_{3}=\mathrm{Pr}$

$5 \mathrm{R}_{1}=\mathrm{OMe}, \mathrm{R}_{2}=\mathrm{Me}, \mathrm{R}_{3}=\mathrm{Pr}$<smiles>[R4]Oc1cc2c(c([R])c1[R])C(=O)c1c(O)cc(O)c(C([R4])=O)c1C2=O</smiles>

$6 \quad \mathrm{R}_{1}=\mathrm{OH}, \mathrm{R}_{2}=\mathrm{H}, \mathrm{R}_{3}=\mathrm{Me}, \mathrm{R}_{4}=\mathrm{Pr}$

$7 \quad \mathrm{R}_{1}=\mathrm{OH}, \mathrm{R}_{2}=\mathrm{H}, \mathrm{R}_{3}=\mathrm{Me}, \mathrm{R}_{4}=\mathrm{Me}$

$8 R_{1}=O M e, R_{2}=H, R_{3}=M e, R_{4}=P r$

$9 R_{1}=O M e, R_{2}=H, R_{3}=M e, R_{4}=M e$

$10 R_{1}=O H, R_{2}=R_{3}=H, R_{4}=P r$

$11 \mathrm{R}_{1}=\mathrm{OH}, \mathrm{R}_{2}=\mathrm{R}_{3}=\mathrm{H}, \mathrm{R}_{4}=\mathrm{Me}$

$12 \mathrm{R}_{1}=\mathrm{OH}, \mathrm{R}_{2}=\mathrm{OMe}, \mathrm{R}_{3}=\mathrm{Me}, \mathrm{R}_{4}=\mathrm{Pr}$<smiles>O=C1c2cc(O)cc(O)c2C(=O)c2cc(O)cc(O)c21</smiles>

13
$14 \mathrm{R}_{1}=\operatorname{Pr}, \mathrm{R}_{2}=\mathrm{R}_{4}=\mathrm{H}, \mathrm{R}_{3}=\mathrm{OMe}$

$15 \mathrm{R}_{1}=\mathrm{Pr}, \mathrm{R}_{2}=\mathrm{Me}, \mathrm{R}_{3}=\mathrm{OMe}, \mathrm{R}_{4}=\mathrm{H}$

$16 R_{1}=M e, R_{2}=R_{4}=H, R_{3}=O M e$

$17 \mathrm{R}_{1}=\mathrm{Pr}, \mathrm{R}_{2}=\mathrm{R}_{4}=\mathrm{Me}, \mathrm{R}_{3}=\mathrm{OMe}$

$18 \mathrm{R}_{1}=\operatorname{Pr}, \mathrm{R}_{2}=\mathrm{R}_{3}=\mathrm{R}_{4}=\mathrm{H}$

Comatulin A (1) was isolated as a red amorphous powder and was assigned the molecular formula $\mathrm{C}_{20} \mathrm{H}_{19} \mathrm{NO}_{10} \mathrm{~S}$ following analysis of the HRESIMS ion at $m / z 464.0643[\mathrm{M}-\mathrm{H}]^{-}$. The ${ }^{1} \mathrm{H}$ 
NMR spectrum (Table 1) of $\mathbf{1}$ in DMSO- $d_{6}$ (trace of TFA) revealed signals corresponding to two meta-coupled aromatic methine doublets $\left(\delta_{\mathrm{H}} 6.89\right.$ and $\left.7.15, J=2.5 \mathrm{~Hz}\right)$, three methylene protons $\left(\delta_{\mathrm{H}} 2.85,3.29\right.$, and 4.25$)$, two methyl singlets $\left(\delta_{\mathrm{H}} 2.42\right.$ and 3.92$)$ and two phenolic protons $\left(\delta_{\mathrm{H}}\right.$ 12.10, and 13.22). The proton resonating at $\delta_{\mathrm{H}} 8.71$ was assigned to a $\mathrm{NH}$ group following HSQC spectrum analysis. The ${ }^{13} \mathrm{C}$ NMR spectrum (Table 2) and the edited HSQC spectra suggested the presence of 20 carbons, including two methyls, three methylenes, two methines and 13 nonprotonated $\mathrm{sp}^{2}$ carbons. The presence of three carbonyl signals at $\delta_{\mathrm{C}} 188.2,181.8$ and 201.6, 10 non-protonated carbons, including four aromatic oxygenated carbons at $\delta_{\mathrm{C}} 161.2,162.7,164.0$ and 165.8, and two aromatic methine carbons at $\delta_{\mathrm{C}} 107.1$ and 107.8 suggested that compound $\mathbf{1}$ contained a 1-acylanthraquinone scaffold, similar to that present in 12-desethylrhodocomatulin 7methyl ether (7). ${ }^{9}$ This was supported by HMBC correlations from the methyl protons $\left(\delta_{\mathrm{H}} 2.42\right)$ to a carbonyl carbon at $\delta_{\mathrm{C}} 201.6\left(\mathrm{C}-1^{\prime}\right)$ and to an aromatic carbon at $\delta_{\mathrm{C}} 127.7(\mathrm{C}-1)$, as well as the coupling between H-6 and H-8 observed in the COSY spectrum (Figure 1). Although compound 1 was missing the H-3 aromatic methine proton present in 7, additional proton NMR resonances at $\delta_{\mathrm{H}} 4.25,3.29$ and 2.85 suggested that $\mathrm{C}-3$ was substituted with a small alkyl moiety. Analysis of the COSY spectrum established a spin system that included a protonated $-\mathrm{CH}_{2} \mathrm{NHCH}_{2} \mathrm{CH}_{2-}$ substructure. The relatively deshielded ${ }^{13} \mathrm{C}$ chemical shift of C-4" at $\delta_{\mathrm{C}} 46.6$ suggested that it was directly attached to a terminal sulfonic acid group, thus forming a $-\mathrm{CH}_{2} \mathrm{NHCH}_{2} \mathrm{CH}_{2} \mathrm{SO}_{3} \mathrm{H}(\mathrm{N}$ methylenetaurine) side chain. The assignment of this side chain was consistent with the NMR data reported for hypalocrinin D, a taurine-conjugated anthraquinone reported previously. ${ }^{15}$ The fragment ion in the HRESIMS at $\mathrm{m} / 2339.0499\left[\mathrm{M}-\mathrm{C}_{2} \mathrm{H}_{7} \mathrm{NO}_{3} \mathrm{~S}\right]^{-}$further supported the presence of this taurine moiety. The HMBC correlations observed from $\mathrm{H}-1$ " $\left(\delta_{\mathrm{H}} 4.25\right)$ to $\mathrm{C}-2\left(\delta_{\mathrm{C}} 161.2\right)$, $\mathrm{C}-4\left(\delta_{\mathrm{C}} 162.7\right), \mathrm{C}-3\left(\delta_{\mathrm{C}} 112.1\right)$ and $\mathrm{C}-3 "$ " $\left(\delta_{\mathrm{C}} 44.3\right)$ (Figure 1) confirmed that the taurine-derived 
side chain was attached to C-3. Consequently, the full structure of $\mathbf{1}$, a methylenetaurine conjugate of 12-desethylrhodocomatulin 7-methyl ether was assigned to comatulin A.

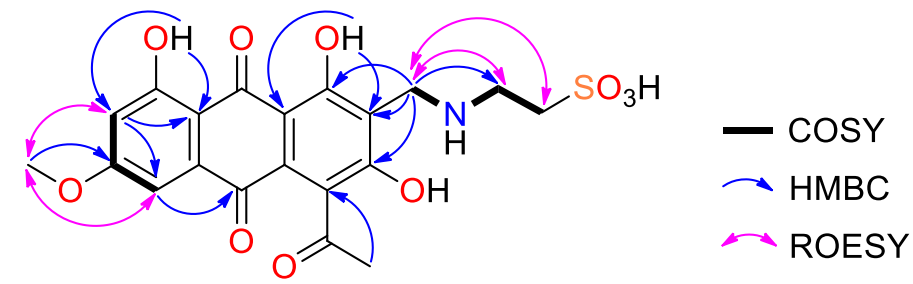

Figure 1. Key COSY, HMBC and ROESY correlations of comatulin A (1).

Comatulin B (2) was purified as a red amorphous powder with a molecular formula of $\mathrm{C}_{22} \mathrm{H}_{23} \mathrm{NO}_{10} \mathrm{~S}$, as suggested by the HRESIMS data $m / \mathrm{z} 492.0947[\mathrm{M}-\mathrm{H}]^{-}$. The fragment ion at $m / z 367.0806\left[\mathrm{M}-\mathrm{C}_{2} \mathrm{H}_{7} \mathrm{NO}_{3} \mathrm{~S}\right]^{-}$indicated that 2 contained a $\mathrm{N}$-methylenetaurine side chain, identical to comatulin A. The ${ }^{1} \mathrm{H}$ NMR spectrum of $\mathbf{2}$ was also very similar to that of $\mathbf{1}$ (Table $\mathbf{1}$ ), however, comatulin B showed additional signals resonating at $\delta_{\mathrm{H}} 0.98,1.72$ and 2.64 , and was missing the methyl ketone resonance present in 1. Analysis of the COSY spectrum revealed a spin system corresponding to an $n$-propyl chain, which accounted for all additional proton NMR signals observed in 2. Furthermore, HMBC data analysis showed correlations from $\mathrm{H}-3^{\prime}\left(\delta_{\mathrm{H}} 1.72\right)$ to $\mathrm{C}-1^{\prime}$ $\left(\delta_{\mathrm{C}} 203.3\right), \mathrm{C}-2^{\prime}\left(\delta_{\mathrm{C}} 44.6\right)$ and $\mathrm{C}-4^{\prime}\left(\delta_{\mathrm{C}} 13.6\right)$ indicating the methyl ketone moiety of 1 had been replaced with a propyl ketone group at $\mathrm{C}-1$ in $\mathbf{2}$. HMBC correlations were also observed from $\mathrm{H}-$ $1 "\left(\delta_{\mathrm{H}} 4.26\right)$ to $\mathrm{C}-2\left(\delta_{\mathrm{C}} 161.0\right), \mathrm{C}-4\left(\delta_{\mathrm{C}} 162.7\right), \mathrm{C}-3\left(\delta_{\mathrm{C}} 112.2\right)$ and $\mathrm{C}-3$ " $\left(\delta_{\mathrm{C}} 44.4\right)$, thus confirming the presence of a C-3 substituted $N$-methylenetaurine side chain in $\mathbf{2}$. Therefore, the structure of $\mathbf{2}$ was established as an $\mathrm{N}$-methylenetaurine-conjugate of rhodocomatulin 7-methyl ether (6), and assigned the trivial name comatulin B.

The molecular formula of 3 was established as $\mathrm{C}_{19} \mathrm{H}_{17} \mathrm{NO}_{10} \mathrm{~S}$ by HRESIMS ( $\mathrm{m} / \mathrm{z} 450.0492$ [M $\mathrm{H}]^{-}$. The ${ }^{1} \mathrm{H}$ and ${ }^{13} \mathrm{C}$ NMR spectra of comatulin $\mathrm{C}(3)$ were almost identical to those of $\mathbf{1}$ (Tables 
1 and 2), except that the signals corresponding to the methoxy group in $\mathbf{1}\left(\delta_{\mathrm{H}} 3.92, \delta_{\mathrm{C}} 56.4\right)$ were absent. Detailed analysis of the HMBC spectrum confirmed the presence of an $N$-methylenetaurine side chain at C-3, based on ${ }^{2} J_{\mathrm{CH}}$ and ${ }^{3} J_{\mathrm{CH}}$ correlations from $\mathrm{H}-1$ " $\left(\delta_{\mathrm{H}} 4.25\right)$ to $\mathrm{C}-2\left(\delta_{\mathrm{C}} 161.1\right), \mathrm{C}-4$ $\left(\delta_{\mathrm{C}} 162.6\right), \mathrm{C}-3\left(\delta_{\mathrm{C}} 112.0\right)$ and $\mathrm{C}-3 "{ }^{\prime \prime}\left(\delta_{\mathrm{C}} 44.3\right)$. This was further supported by the characteristic fragment peak in the LRESIMS spectrum at $m / \mathrm{z} 325\left[\mathrm{M}-\mathrm{C}_{2} \mathrm{H}_{7} \mathrm{NO}_{3} \mathrm{~S}\right]^{-}$and thus the chemical structure of comatulin $\mathrm{C}$ was assigned to 3 .

The minor metabolite, comatulin D (4), was assigned the molecular formula $\mathrm{C}_{21} \mathrm{H}_{21} \mathrm{NO}_{10} \mathrm{~S}[\mathrm{M}-$ $\mathrm{H}]^{-}$following HRESIMS data analysis. The ${ }^{1} \mathrm{H}$ NMR data of 4 closely resembled those of 3 (Table 1), with the difference being the presence of additional signals at $\delta_{\mathrm{H}} 0.97,1.70$ and 2.60. Through analysis of COSY correlations, these additional signals were assigned to an $n$-propyl chain, suggesting the presence of a propyl ketone unit at $\mathrm{C}-1$, similar to that observed in 2 . Owing to the paucity of material (0.8 mg), several carbon chemical shifts (i.e., C-1, C-2, C-4a, C-7, C-9a, C-10, C-1') were not observed. The fragment ion in the LRESIMS spectrum at $\mathrm{m} / \mathrm{z} 353$ [M $\left.\mathrm{C}_{2} \mathrm{H}_{7} \mathrm{NO}_{3} \mathrm{~S}\right]^{-}$, in conjunction with the $\mathrm{HMBC}$ correlations from $\delta_{\mathrm{H}} 4.19$ to $\delta_{\mathrm{C}} 111.3,162.8$, and 44.2 revealed that 4 also contained an $N$-methylenetaurine moiety attached at C-3. Consequently, the chemical structure of $\mathbf{4}$ was assigned to comatulin D.

Comatulin E (5) was obtained as a red amorphous powder from the other specimen of $C$. rotalaria. The molecular formula of 5 was assigned as $\mathrm{C}_{23} \mathrm{H}_{25} \mathrm{NO}_{11} \mathrm{~S}$, as determined by HRESIMS $\left(\mathrm{m} / \mathrm{z} 522.1074[\mathrm{M}-\mathrm{H}]^{-}\right.$. The ${ }^{1} \mathrm{H}$ NMR spectrum indicated that $\mathbf{5}$ had similar features to $\mathbf{2}$ (Table 1), except for the presence of an additional methoxy signal $\left(\delta_{\mathrm{H}} 3.85, \delta_{\mathrm{C}} 60.4\right)$ and only one noncoupled aromatic proton at $\delta_{\mathrm{H}} 7.34$ was observed, indicating the aromatic proton $\left(\delta_{\mathrm{H}} 6.89\right)$ at C-6 in $\mathbf{2}$ had been replaced by a methoxy group in 5. Analysis of the HMBC spectrum revealed the methoxy group $\left(\delta_{\mathrm{H}} 3.99\right)$ was attached to $\mathrm{C}-7\left(\delta_{\mathrm{C}} 158.1\right)$, and it was adjacent to the aromatic proton 
singlet $\left(\delta_{H} 7.34\right)$ as indicated by the ROESY spectrum (Figure 2). The methoxy group $\left(\delta_{H} 3.85\right)$ was assigned at C- 6 following the HMBC correlation observed from both $\delta_{\mathrm{H}} 7.34$ and $\delta_{\mathrm{H}} 3.85$ to $\delta_{\mathrm{C}}$ 141.4. This substitution pattern was further confirmed by the notably shielded chemical shift of C-6 $\left(\delta_{\mathrm{C}} 141.4\right)$ as compared to $\mathrm{C}-7\left(\delta_{\mathrm{C}} 158.1\right)$, which was consistent with an OMe substituted aromatic carbon with two ortho oxygenated groups (i.e, 7-OMe and 5-OH), a substitution observed for $12 .{ }^{9}$ The fragment ion in the HRESIMS spectrum at $\mathrm{m} / \mathrm{z} 397.0929\left[\mathrm{M}-\mathrm{C}_{2} \mathrm{H}_{7} \mathrm{NO}_{3} \mathrm{~S}\right]^{-}$and HMBC correlations from $\mathrm{H}-1$ " to C-2, C-3, C-4 and C-3" were again observed, indicating that like the previously elucidated comatulins A-D, an $N$-methylenetaurine side chain was positioned at C3. Hence, comatulin E was assigned to structure 5 .

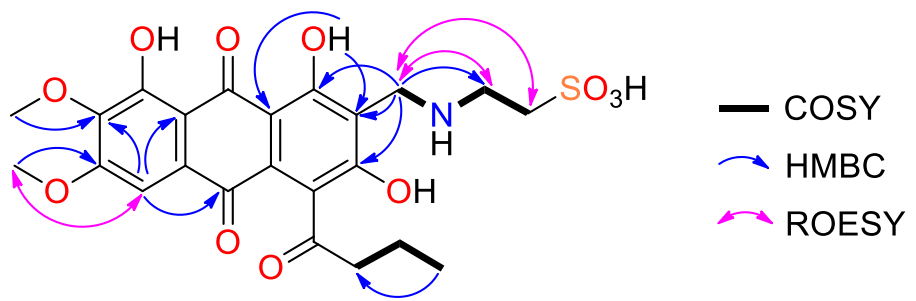

Figure 2. Key COSY, HMBC and ROESY correlations of comatulin E (5). 
Table 1. ${ }^{1} \mathrm{H}$ NMR Spectroscopic Data $\left(800 \mathrm{MHz}, \mathrm{DMSO}-d_{6}+\right.$ trace TFA) for Comatulins A-E (1-5)

\begin{tabular}{|c|c|c|c|c|c|}
\hline \multirow{2}{*}{ position } & 1 & 2 & 3 & 4 & 5 \\
\hline & $\delta_{\mathrm{H}}$, mult. $(J$ in $\mathrm{Hz})$ & $\delta_{\mathrm{H}}$, mult. $(J$ in Hz$)$ & $\delta_{\mathrm{H}}$, mult. $(J$ in $\mathrm{Hz})$ & $\delta_{\mathrm{H}}$, mult. $(J$ in $\mathrm{Hz})$ & $\delta_{\mathrm{H}}$, mult. $(J$ in $\mathrm{Hz})$ \\
\hline $2-\mathrm{OH}$ & $a$ & $a$ & $a$ & $a$ & $a$ \\
\hline $4-\mathrm{OH}$ & $13.22, \mathrm{~s}$ & $13.23, \mathrm{~s}$ & 13.29, s & $13.32, \mathrm{~s}$ & $13.14, \mathrm{~s}$ \\
\hline $5-\mathrm{OH}$ & $12.10, \mathrm{~s}$ & $12.04, \mathrm{~s}$ & $12.03, \mathrm{~s}$ & $12.17^{b}$, br s & $a$ \\
\hline 6 & $6.89, \mathrm{~d}(2.5)$ & $6.88, \mathrm{~d}(2.5)$ & $6.63, \mathrm{~d}(2.3)$ & $6.60, \mathrm{~d}(2.4)$ & \\
\hline 6-OMe & & & & & $3.85, \mathrm{~s}$ \\
\hline 7-OH & & & $a$ & $11.30^{b}$, br s & \\
\hline 7-OMe & $3.92, \mathrm{~s}$ & $3.92, \mathrm{~s}$ & & & 3.99, s \\
\hline 8 & $7.15, \mathrm{~d}(2.5)$ & $7.13, \mathrm{~d}(2.5)$ & $7.07, \mathrm{~d}(2.3)$ & $7.03, \mathrm{~d}(2.4)$ & $7.34, \mathrm{~s}$ \\
\hline $2^{\prime}$ & $2.42, \mathrm{~s}$ & 2.64, br s & $2.41, \mathrm{~s}$ & 2.60, br s & 2.61, br s \\
\hline $3^{\prime}$ & & $1.72, \mathrm{qt}(7.4,7.4)$ & & $1.70, \mathrm{qt}(7.4,7.4)$ & 1.72 , br qt $(7.5,7.5)$ \\
\hline $4^{\prime}$ & & $0.98, \mathrm{t}(7.4)$ & & $0.97, \mathrm{t}(7.4)$ & $0.98, \mathrm{t}(7.5)$ \\
\hline $1 "$ & $4.25, \mathrm{~s}$ & $4.26, \mathrm{~s}$ & $4.25, \mathrm{~s}$ & $4.19, \mathrm{~s}$ & $4.26, \mathrm{~s}$ \\
\hline $2^{\prime \prime}(\mathrm{NH})$ & 8.71, br s & 8.72, br s & 8.72, br s & $a$ & 8.72 , br s \\
\hline $3^{\prime \prime}$ & $3.29, \mathrm{t}(6.6)$ & 3.30 , br t $(6.6)$ & 3.28, br t $(6.6)$ & 3.26 , br t $(6.6)$ & 3.30 , br t $(6.6)$ \\
\hline 4" & $2.85, \mathrm{t}(6.6)$ & $2.86, \mathrm{t}(6.6)$ & $2.85, \mathrm{t}(6.6)$ & $2.84, \mathrm{t}(6.6)$ & $2.85, \mathrm{t}(6.6)$ \\
\hline
\end{tabular}

${ }^{a}$ Not observed

${ }^{b}$ Interchangeable signals 
Table 2. ${ }^{13} \mathrm{C}$ NMR Spectroscopic Data $\left(200 \mathrm{MHz}, \mathrm{DMSO}-d_{6}+\right.$ trace TFA) for Comatulins A-E (1-5)

\begin{tabular}{|c|c|c|c|c|c|}
\hline \multirow{2}{*}{ position } & 1 & 2 & 3 & 4 & 5 \\
\hline & $\delta_{\mathrm{C}}$, type & $\delta_{\mathrm{C}}$, type & $\delta_{\mathrm{C}}$, type & $\delta_{\mathrm{C}}$, type & $\delta_{\mathrm{C}}$, type \\
\hline 1 & $127.7, \mathrm{C}$ & $127.4, \mathrm{C}$ & $127.5, \mathrm{C}$ & $b$ & $b$ \\
\hline 2 & $161.2, \mathrm{C}^{a}$ & $161.0, \mathrm{C}$ & $161.1, \mathrm{C}^{a}$ & $b$ & $161.0, \mathrm{C}^{a}$ \\
\hline 3 & $112.1, \mathrm{C}$ & $112.2, \mathrm{C}$ & $112.0, \mathrm{C}$ & $111.3, \mathrm{C}^{a}$ & $112.0, \mathrm{C}$ \\
\hline 4 & $162.7, \mathrm{C}$ & $162.7, \mathrm{C}$ & $162.6, \mathrm{C}$ & $162.8, \mathrm{C}$ & $162.7, \mathrm{C}$ \\
\hline $4 a$ & $106.9, \mathrm{C}$ & $107.4, \mathrm{C}$ & $106.8, \mathrm{C}$ & & $107.8, \mathrm{C}^{a}$ \\
\hline 5 & $164.0, \mathrm{C}$ & $164.0, \mathrm{C}$ & 164.0, C & $163.8, \mathrm{C}$ & $155.3, \mathrm{C}$ \\
\hline 6 & 107.1, CH & 107.1, CH & $108.4, \mathrm{CH}$ & $108.4, \mathrm{CH}$ & $141.4, \mathrm{C}$ \\
\hline 6-OMe & & & & & $60.4, \mathrm{CH}_{3}$ \\
\hline 7 & $165.8, \mathrm{C}$ & $165.9, \mathrm{C}$ & 165.2, C & $b$ & $158.1, \mathrm{C}$ \\
\hline 7-OMe & $56.4, \mathrm{CH}_{3}$ & $56.4, \mathrm{CH}_{3}$ & & & $56.6, \mathrm{CH}_{3}$ \\
\hline 8 & $107.8, \mathrm{CH}$ & $107.8, \mathrm{CH}$ & $108.9, \mathrm{CH}$ & 108.7, CH & $104.8, \mathrm{CH}$ \\
\hline $8 a$ & $134.3, \mathrm{C}$ & 134.3, C & 134.6, C & $134.5, \mathrm{C}$ & $128.4, \mathrm{C}$ \\
\hline 9 & $181.8, \mathrm{C}$ & $181.6, \mathrm{C}$ & $182.0, \mathrm{C}$ & $182.2, \mathrm{C}^{a}$ & 181.1, C \\
\hline $9 a$ & $130.6, \mathrm{C}$ & $130.8, \mathrm{C}$ & $130.6, \mathrm{C}$ & $b$ & $130.7, \mathrm{C}$ \\
\hline 10 & $188.2, \mathrm{C}$ & $188.5, \mathrm{C}$ & $188.1, \mathrm{C}$ & $b$ & 189.1, C \\
\hline $10 \mathrm{a}$ & $109.6, \mathrm{C}$ & $109.5, \mathrm{C}$ & $108.6, \mathrm{C}$ & $108.6, \mathrm{C}$ & $111.2, \mathrm{C}$ \\
\hline $1^{\prime}$ & $201.6, \mathrm{C}$ & 203.3, C & 201.6, C & $b$ & 203.3, C \\
\hline $2^{\prime}$ & $31.0, \mathrm{CH}_{3}$ & $44.6, \mathrm{CH}_{2}$ & $31.0, \mathrm{CH}_{3}$ & $44.5, \mathrm{CH}_{2}$ & $44.7, \mathrm{CH}_{2}$ \\
\hline $3^{\prime}$ & & $16.4, \mathrm{CH}_{2}$ & & $16.4, \mathrm{CH}_{2}$ & $16.4, \mathrm{CH}_{2}$ \\
\hline $4^{\prime}$ & & $13.6, \mathrm{CH}_{3}$ & & $13.6, \mathrm{CH}_{3}$ & $13.6, \mathrm{CH}_{3}$ \\
\hline $1^{\prime \prime}$ & $39.2, \mathrm{CH}_{2}$ & $39.2, \mathrm{CH}_{2}$ & $39.2, \mathrm{CH}_{2}$ & $39.3, \mathrm{CH}_{2}$ & $39.2, \mathrm{CH}_{2}$ \\
\hline $3^{\prime \prime}$ & $44.3, \mathrm{CH}_{2}$ & $44.4, \mathrm{CH}_{2}$ & $44.3, \mathrm{CH}_{2}$ & $44.2, \mathrm{CH}_{2}$ & $44.4, \mathrm{CH}_{2}$ \\
\hline 4" & $46.6, \mathrm{CH}_{2}$ & $46.6, \mathrm{CH}_{2}$ & $46.6, \mathrm{CH}_{2}$ & $46.6, \mathrm{CH}_{2}$ & $46.6, \mathrm{CH}_{2}$ \\
\hline
\end{tabular}

${ }^{a 13} \mathrm{C}$ chemical shift obtained through HMBC experiments

${ }^{b}$ Not observed 
The chemical structures of the known compounds (6-16) were also confirmed by detailed 1D/2D NMR and MS data analysis. The NMR spectroscopic data of the known compound rhodocomatulin (10), first isolated in $1959^{11}$ is reported in this work because no ${ }^{13} \mathrm{C}$ and $2 \mathrm{D}$ NMR data have been recorded to date. We also report the full ${ }^{13} \mathrm{C} N M R$ data for $6-$ methoxyrhodocomatulin 7-methyl ether (12) as several carbon chemical shifts (i.e. C-2, C-8a, C9a, C-10, C-11) were not observed in the previous study due to paucity of material. ${ }^{9}$ Furthermore, we undertook crystallography studies of the three most abundant anthraquinones (6-8) purified in these studies, as no X-ray structure of crinoid-derived acyl anthraquinone have been reported. Crystallization with $\mathrm{EtOH}, \mathrm{MeOH}$ and acetone on $\mathbf{6}$ and $\mathbf{7}$ initially proved unsuccessful after multiple attempts; however, compound $\mathbf{8}$ finally crystallized from EtOH under slow evaporation at room temperature. A single crystal X-ray diffraction study was performed on the rhodocomatulin 5,7-dimethyl ether (8) (Figure 3), which definitively confirmed the structure of 8 . This is the first report of a crinoid-derived acyl anthraquinone X-ray structure.

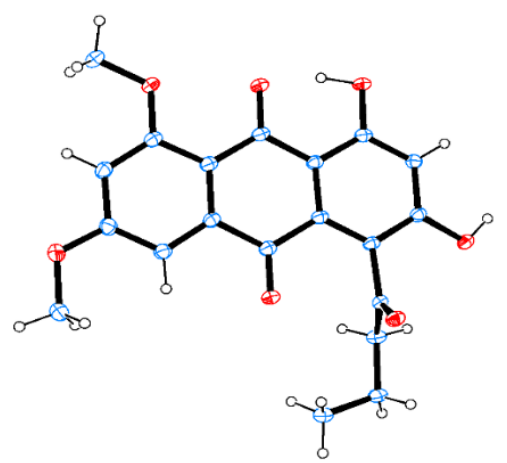

Figure 3. ORTEP drawing of rhodocomatulin 5,7-dimethyl ether (8). The water molecule has been omitted for clarity.

Anthraquinone derivatives have been reported to exert anti-HIV activity by inhibiting HIV-1 reverse transcriptase, as well as through the inhibition of reverse transcriptase-associated ribonuclease $\mathrm{H}$ function. ${ }^{16,17}$ Our previous studies reported a subset of naphthopyrones that were 
found to display moderate inhibition of HIV-1 replication in a $\mathrm{T}$ cell line, with $\mathrm{EC}_{50}$ values ranging from 7.5 to $26 \mu \mathrm{M} .^{7}$ It was also observed that comaparvin (18), which only contains one methoxy group, exhibited an approximately 2.0 -fold increase in HIV-1 inhibitory activity compared with 6methoxycomaparvin-5-methyl ether (15), ${ }^{7}$ which contains three methoxy groups. In order to facilitate additional structure-activity relationships in the current study, we methylated the abundant natural product, 6-methoxycomaparvin 5-methyl ether (15) to generate the known tetramethoxy derivative, 6-methoxycomaparvin 5,8-dimethyl ether (17). ${ }^{18}$ In the current study, we tested the 10 most abundant anthraquinones $(\mathbf{1}, \mathbf{2}, \mathbf{6}-\mathbf{1 3})$, together with the comaparvin derivatives (14 and 17) for anti-HIV-1 multicycle replication and anthelmintic activity using established assays. ${ }^{8,19}$ Comaparvin (18) isolated from previous studies was also incorporated into the screening. ${ }^{7}$ Consistent with previous results, comaparvin (18) inhibited HIV-1 replication with an $\mathrm{EC}_{50}$ of $5.7 \pm 0.8 \mu \mathrm{M}$, whereas all of the tested compounds exhibited $\mathrm{EC}_{50}$ values $>100 \mu \mathrm{M}$ against HIV-1 replication. Therefore, we concluded that multiple methoxy groups on the comaparvin scaffold did not improve HIV-1 replication.

Furthermore, compounds 1, 2, 6-10, 14-15, 17-18 were screened for nematocidal activity against Haemonchus contortus, a highly pathogenic parasitic nematode of ruminants. ${ }^{20}$ Compound 17 showed a reduction in the motility of exsheathed third-stage larvae (xL3) after $72 \mathrm{~h}$ treatment, with an $\mathrm{IC}_{50}$ of $30 \mu \mathrm{M}$ (Figure 4A). Compounds 10 and 17 significantly inhibited the development of xL3 to fourth-stage larvae (L4) after seven days of exposure to $100 \mu \mathrm{M}$ of each of these compounds (Figure 4B). Following a dose-response evaluation, compound 17 was shown to inhibit the development at much lower concentrations, with an $\mathrm{IC}_{50}$ value of $31 \mu \mathrm{M}$ (Figure 4C). When treated with compound $\mathbf{1 7}$ at $100 \mu \mathrm{M}, 51 \%$ of xL3 exhibited an abnormal morphological phenotype on day seven (Figure 5). Larvae with this evisceration (Evi) phenotype, observed 
previously, ${ }^{21}$ are characterized by a protrusion of the alimentary tract and tissues through the excretory pore. Some xL3s treated with lower concentrations of compound $\mathbf{1 7}$ developed to fourthstage larvae (L4s). Although the Evi phenotype was not observed at the L4 stages, alterations were observed in other internal structures of this stage were seen by light microscopic examination (Figure 5). The Evi phenotype and internal changes were observed neither in wildtype L3s nor in developed (unexposed control) L4s. ${ }^{21}$ While four angular naphthopyrones $(\mathbf{1 4}, \mathbf{1 5}, \mathbf{1 7}, \mathbf{1 8})$ were tested, the activity identified for compound $\mathbf{1 7}$ may be due to higher lipophilicity of this molecule compared with other compounds in this series. The calculated $\log \mathrm{P}$ of 17 was 2.39 , compared with $\log \mathrm{P}$ values of $1.87,2.13$, and 1.99 for compounds $\mathbf{1 4}, \mathbf{1 5}$, and $\mathbf{1 8}$, respectively. ${ }^{22}$

$\mathbf{A}$

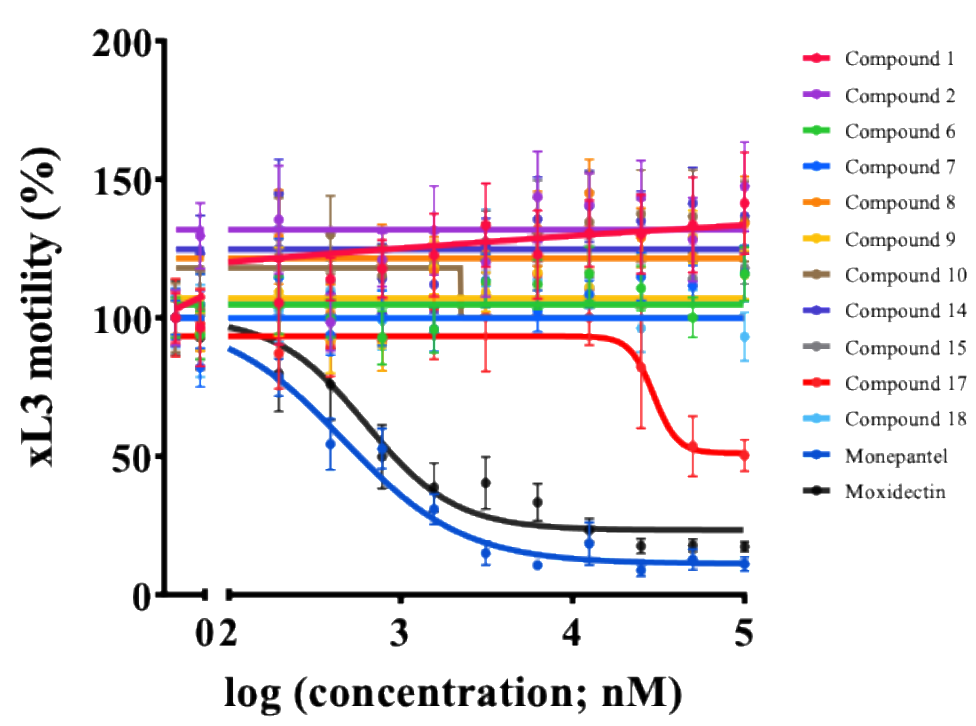

B

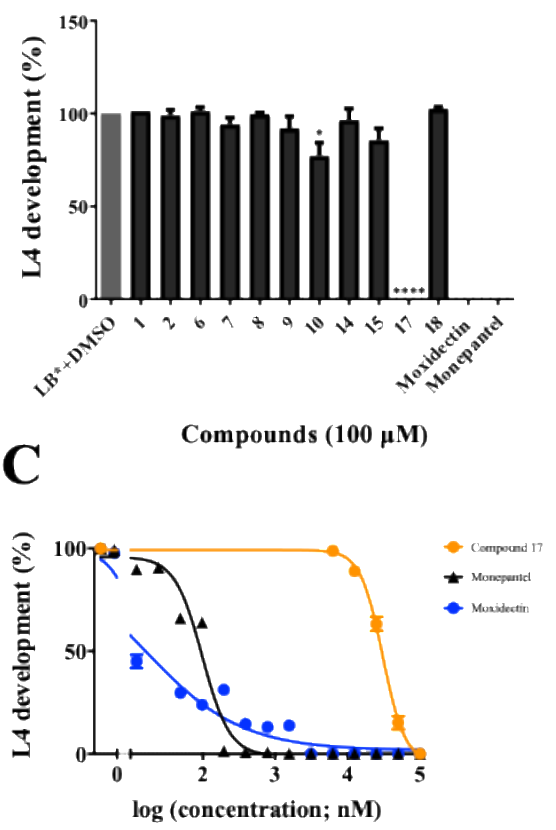

Figure 4. Compounds effect against exsheathed third-stage larvae (xL3) Haemonchus contortus in vitro. (A) Dose-response curves of the effects of 11 compounds (compounds 1, 2, 6-10, 14, 15, 17,18 ) on the inhibition of motility at $72 \mathrm{~h}$, and (B) development of xL3 to fourth-stage larvae (L4) at $100 \mu \mathrm{M}$ on seventh day. (C) Dose-response curve of compound 17 on L4 development. 
Data points represent three experiments conducted in triplicates, presented as the mean \pm SEM. Monepantel and moxidectin served as reference compounds. ${ }^{*}$ and ${ }^{* * * *}$ denote for $p$ values of 0.016 and $<0.001$, respectively.
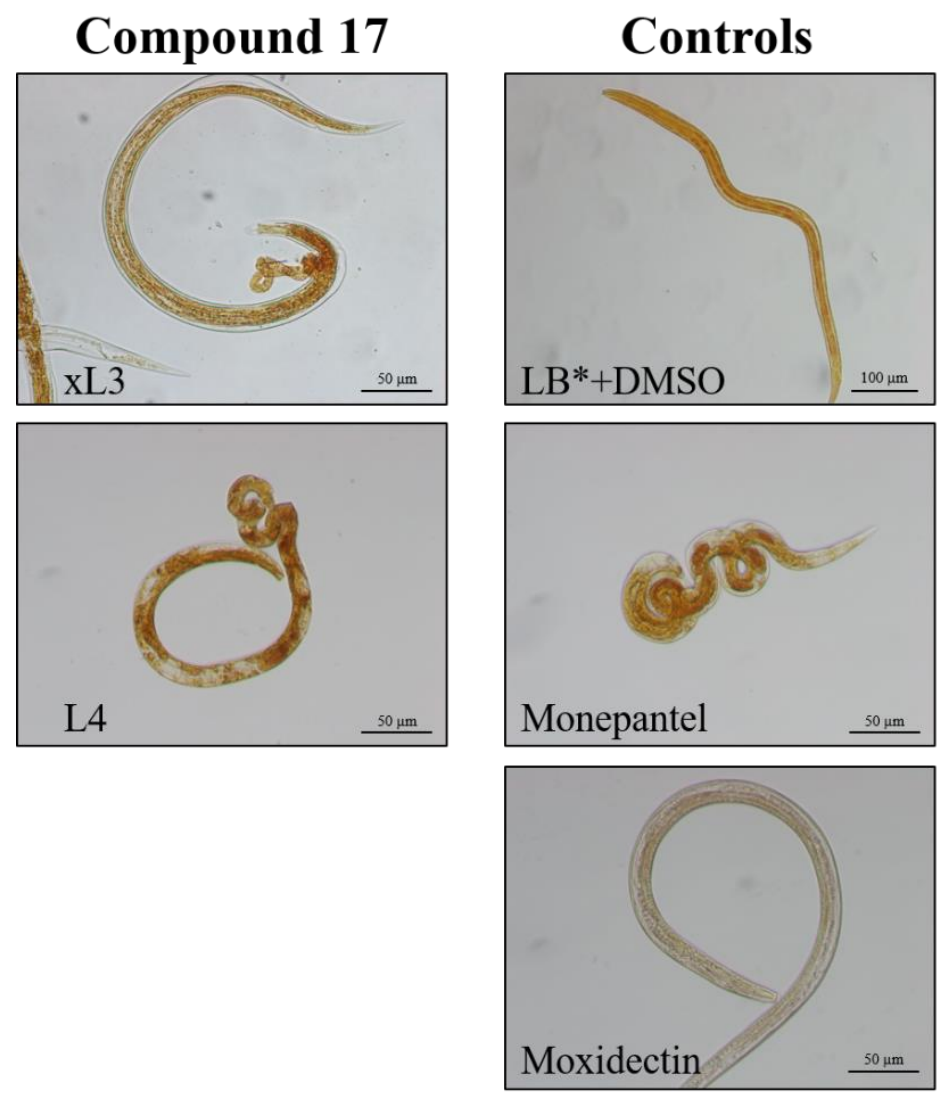

Anterior end

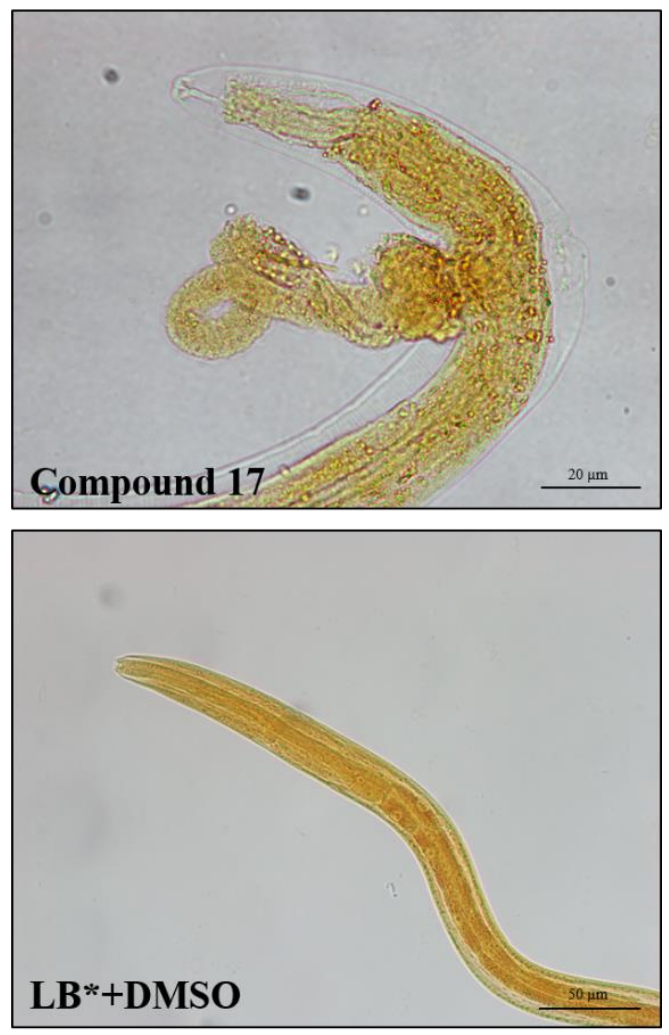

Figure 5. Microscopic images of compound-treated exsheathed third-stage larvae (xL3) Haemonchus contortus and fourth-stage larvae (L4). Evi (evisceration) phenotype induced in xL3 after seven days of treatment with compound 17 compared with monepantel and moxidectin used as reference for abnormal phenotypes and negative control treated corresponding concentration of dimethyl sulfoxide (DMSO).

Previous chemical investigations of the pigments of Australian crinoids have described acyl derivatives of anthraquinone as the predominant polyketide in the genus Comatula. ${ }^{8,911,12}$ In 1981, 
a follow-up study of the crinoid C. pectinata isolated rhodocomatulin 5,7-dimethyl ether (8) in the form of a sulfate ester from the aqueous-soluble material of acetone extract. ${ }^{23}$ In the present study, we report the first isolation of five new methylenetaurine-acyl anthraquinone derivatives from $n$ $\mathrm{BuOH}$-soluble material of the $\mathrm{MeOH}$ and $\mathrm{MeOH} / \mathrm{H}_{2} \mathrm{O}(1: 1)$ extracts of two C. rotalaria specimens, and 11 known compounds from the $\mathrm{CH}_{2} \mathrm{Cl}_{2}$ extracts and EtOAc-soluble extracts. No sulfate esters of acylanthraquinones were observed in the extracts of our crinoid specimens. In comparison to the first report on the chemistry of $C$. rotalaria, since Francesconi had only investigated the chloroform-soluble material of acetone extract, it can be postulated that the water-soluble constituent may also contains the highly polar taurine-conjugated anthraquinones. ${ }^{8,23}$ Taurineconjugated anthraquinones were first reported from the deep sea crinoid Hypalocrinus naresianus, ${ }^{15}$ suggesting that the taurine-conjugated metabolites may also be present in other polyketide pigments derived from crinoids. Although acyl-anthraquinone derivatives have been isolated in several studies, ${ }^{8,9,11,12,23}$ the biological properties of these compounds have remained overlooked due to a paucity of materials. Therefore, we screened the most abundant anthraquinones, together with several naphthopyrones, in the HIV replication and anthelmintic assays. While none of the anthraquinones were active in these assays, a semi-synthetic derivative, 6-methoxycomaparvin 5,8-dimethyl ether (17), showed moderate activity against the xL3 stage of H. contortus. These studies indicate that crinoid metabolites and their derivatives may be worthy of further anthelmintic evaluation. 


\section{EXPERIMENTAL SECTION}

General Experimental Procedures. Melting point was measured using a Cole-Parmer melting point apparatus and are uncorrected. UV spectra were recorded using a JASCO V-650 UV/Vis spectrophotometer. IR data were acquired on Universal Attenuated Total Reflectance (UATR) Two attachment on a PerkinElmer spectrometer. NMR spectra were recorded at $25{ }^{\circ} \mathrm{C}$ on a Bruker AVANCE III HD $800 \mathrm{MHz}$ NMR spectrometer equipped with a cryoprobe. The ${ }^{1} \mathrm{H}$ and ${ }^{13} \mathrm{C}$ chemical shifts were referenced to solvent peaks for DMSO- $d_{6}$ at $\delta_{\mathrm{H}} 2.50$ and $\delta \mathrm{c} 39.52$, respectively. LRESIMS data were recorded on an Ultimate 3000 RS UHPLC coupled to a Thermo Fisher Scientific MSQ Plus single quadruple ESI mass spectrometer. HRESIMS data were acquired on a Bruker maXis II ETD ESI-qTOF. Alltech Davisil 30-40 $\mu \mathrm{m} 60$ Å diol-bonded silica was packed into an open glass column $(125 \times 38 \mathrm{~mm})$ for diol flash column chromatography. Alltech $\mathrm{C}_{18}$ bonded silica $(35-75 \mu \mathrm{m}, 150 \AA$ ) was used for pre-adsorption work before HPLC separations, and the pre-absorbed sample was packed into an Alltech stainless steel guard cartridge $(10 \times 30 \mathrm{~mm})$. A Thermo Fisher Scientific Dionex Ultimate 3000 UHPLC was used for semipreparative HPLC separations. For NP-HPLC, a YMC-Pack Diol $(5 \mu \mathrm{m}, 120 \AA, 150 \times 20 \mathrm{~mm})$ column was used. Thermo Electron Betasil $\mathrm{C}_{18}(5 \mu \mathrm{m}, 100 \AA ̊ .150 \times 21.2 \mathrm{~mm})$, Phenomenex Luna $\mathrm{C}_{18}(5 \mu \mathrm{m}, 90-110 \AA$, $250 \times 10 \mathrm{~mm})$, and Phenomenex Luna phenyl-hexyl $(5 \mu \mathrm{m}, 90-110 \AA, 250$ $\times 10 \mathrm{~mm}$ ) were used for RP-HPLC. All solvents used for chromatography, UV and MS were Honeywell Burdick \& Jackson or Lab-Scan HPLC grade. $\mathrm{H}_{2} \mathrm{O}$ was filtered using a Sartorius Stedium Arium Pro VF ultrapure water system.

Animal Material. Two specimens (SBD517512 and SBD522143) of Comatula rotalaria were collected from the Great Barrier Reef, Queensland, Australia by CSIRO on the ship RV Gwendoline May, which was part of the Seabed Biodiversity (SBD) project. Specimen 
SBD517512 was collected on the $27^{\text {th }}$ of April 2004 at a depth of $32 \mathrm{~m}\left(21^{\circ} 36.9^{\prime}\right.$ South $149^{\circ} 59.1^{\prime}$ East) and specimen SBD522143 was collected on the $28^{\text {th }}$ of September 2004 at a depth of $27 \mathrm{~m}$ $\left(11^{\circ} 0.3^{\prime}\right.$ South $143^{\circ} 18.3^{\prime}$ East). A voucher specimen of C.rotalaria has been deposited at the Queensland Museum, South Brisbane, Queensland, Australia. Both samples were immediately frozen at $-20^{\circ} \mathrm{C}$ upon collection and later transported to the Griffith Institute for Drug Discovery, where they were freeze-dried and ground into a fine powder, and then stored in NatureBank biota repository.

Extraction and Isolation. The freeze-dried and ground specimens of C. rotalaria (20 g each) were extracted exhaustively with $\mathrm{CH}_{2} \mathrm{Cl}_{2}(500 \mathrm{~mL} \times 2), \mathrm{MeOH}(500 \mathrm{~mL} \times 2), \mathrm{MeOH} / \mathrm{H}_{2} \mathrm{O}(1: 1$, $500 \mathrm{~mL} \times 2)$, and $\mathrm{MeOH} / \mathrm{H}_{2} \mathrm{O}(1: 9,500 \mathrm{~mL} \times 2)$.

For C. rotalaria (SBD517512), the brown $\mathrm{CH}_{2} \mathrm{Cl}_{2}$ extract (237.8 $\mathrm{mg}$ ) was subjected to diolbonded silica flash column chromatography using a stepwise solvent gradient from $100 \% n$-hexane to $100 \%$ EtOAc followed by $100 \% \mathrm{MeOH}$ to give 102 fractions. Each fraction was analyzed by silica TLC ( $n$-hexane-EtOAc), and those displaying similar TLC profiles were combined to afford eight fractions (F1-F8); all these fractions were analyzed by ${ }^{1} \mathrm{H}$ NMR spectroscopy. F6 (25.4 mg) was pre-absorbed onto diol-bonded silica gel, packed into a guard cartridge, and attached to a semipreparative diol HPLC column. A linear gradient from $6 \% i$-PrOH/94\% $n$-hexane to $20 \% i$ $\operatorname{PrOH} / 80 \% n$-hexane at a flowrate of $9 \mathrm{~mL} / \mathrm{min}$ was performed over $120 \mathrm{~min}$ to afford

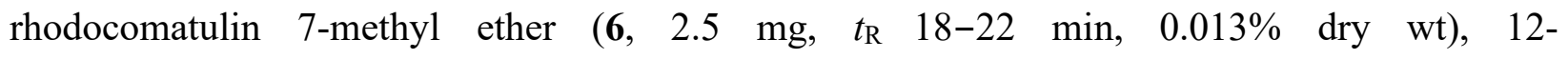
desethylrhodocomatulin 7-methyl ether (7,3.0 $\mathrm{mg}, t_{\mathrm{R}} 25-32 \mathrm{~min}, 0.015 \%$ dry wt), rhodocomatulin 5,7-dimethyl ether (8,17.3 mg, $t_{\mathrm{R}} 44-56 \mathrm{~min}, 0.087 \%$ dry wt) and 12-desethylrhodocomatulin 5,7dimethyl ether $\left(\mathbf{9}, 0.5 \mathrm{mg}, t_{\mathrm{R}} 58-59 \mathrm{~min}, 0.003 \%\right.$ dry wt). The red $\mathrm{MeOH}$ extract $(902.2 \mathrm{mg})$ was resuspended in $\mathrm{H}_{2} \mathrm{O}(100 \mathrm{~mL})$ and then partitioned sequentially with EtOAc $(4 \times 100 \mathrm{~mL})$, then $n$ - 
$\mathrm{BuOH}(4 \times 100 \mathrm{~mL})$. The EtOAc-soluble extract $(145.5 \mathrm{mg})$ was purified by diol HPLC column using a linear gradient from 5\% $i$-PrOH/95\% $n$-hexane to $20 \% i$-PrOH/ $80 \% n$-hexane over 120 min to give rheoemodin $\left(\mathbf{1 3}, 0.8 \mathrm{mg}, t_{\mathrm{R}} 49-53 \mathrm{~min}, 0.004 \%\right.$ dry wt), and rhodocomatulin $(\mathbf{1 0}, 2.0$ $\mathrm{mg}, t_{\mathrm{R}} 55-58 \mathrm{~min} 0.010 \%$ dry wt). The fractions eluting at $t_{\mathrm{R}} 31-33 \mathrm{~min}(3.6 \mathrm{mg})$ were combined and subjected to $\mathrm{C}_{18}$ Luna HPLC column with a linear gradient from $60 \% \mathrm{MeOH} / 40 \% \mathrm{H}_{2} \mathrm{O}(0.1 \%$ TFA) to $100 \% \mathrm{MeOH}(0.1 \% \mathrm{TFA})$ over $60 \mathrm{~min}$ at a flow rate of $4 \mathrm{~mL} / \mathrm{min}$ to yield 6 methoxyrhodocomatulin 7-methyl ether (12, $0.6 \mathrm{mg}, t_{\mathrm{R}} 29-30 \mathrm{~min}, 0.003 \%$ dry wt). Fractions $68-$ 74 (4.2 mg) were purified using $\mathrm{C}_{18}$ Luna HPLC column with a linear gradient solvent system of $60 \% \mathrm{MeOH} / 40 \% \mathrm{H}_{2} \mathrm{O}(0.1 \% \mathrm{TFA})$ to $85 \% \mathrm{MeOH} / 15 \% \mathrm{H}_{2} \mathrm{O}(0.1 \% \mathrm{TFA})$ over $60 \mathrm{~min}$ at a flow rate of $4 \mathrm{~mL} / \mathrm{min}$ to furnish rhodolamprometrin $\left(\mathbf{1 1}, 0.7 \mathrm{mg}, t_{\mathrm{R}} 18-19 \mathrm{~min}, 0.004 \% \mathrm{dry} \mathrm{wt}\right)$. The n-BuOH-soluble material (298.2 mg) was pre-adsorbed onto $\mathrm{C}_{18}$-bonded Si gel ( $\left.\sim \mathrm{g}\right)$, packed into a guard cartridge, and attached to a $\mathrm{C}_{18}$ Betasil HPLC column. Isocratic conditions of $10 \%$ $\mathrm{MeOH} / 90 \% \mathrm{H}_{2} \mathrm{O}$ were held for $15 \mathrm{~min}$, followed by a linear gradient to $75 \% \mathrm{MeOH} / 25 \% \mathrm{H}_{2} \mathrm{O}$ for $95 \mathrm{~min}$, and further eluted with a gradient to $100 \% \mathrm{MeOH}$ for $10 \mathrm{~min}$, all at a flow rate of 9 $\mathrm{mL} / \mathrm{min}$. Fractions $61-63$ and $74-78$ contained the new compounds comatulin A (1, 4.2 $\mathrm{mg}$, $0.021 \%$ dry wt) and comatulin B (2, $5.2 \mathrm{mg}, 0.026 \%$ dry wt), respectively. Fractions $47-50$ (2.8 $\mathrm{mg}$ ) were combined and further purified using a $\mathrm{C}_{18}$ Luna HPLC column with a linear gradient from $20 \% \mathrm{MeOH} / 80 \% \mathrm{H}_{2} \mathrm{O}\left(0.1 \%\right.$ TFA) to $70 \% \mathrm{MeOH} / 30 \% \mathrm{H}_{2} \mathrm{O}(0.1 \% \mathrm{TFA})$ over $60 \mathrm{~min}$ at a flow rate of $4 \mathrm{~mL} / \mathrm{min}$ to yield comatulin $\mathrm{C}\left(3,1.2 \mathrm{mg}, t_{\mathrm{R}} 37-38 \mathrm{~min}, 0.006 \%\right.$ dry wt). Fractions 64-65 (1.3 mg) were pooled and separated using $\mathrm{C}_{18}$ Luna HPLC with a linear gradient from $40 \%$ $\mathrm{MeOH} / 60 \% \mathrm{H}_{2} \mathrm{O}\left(0.1 \%\right.$ TFA) to $80 \% \mathrm{MeOH} / 20 \% \mathrm{H}_{2} \mathrm{O}(0.1 \%$ TFA) over 60 min at a flow rate of $4 \mathrm{~mL} / \mathrm{min}$ to yield comatulin $\mathrm{D}\left(4,0.8 \mathrm{mg}, t_{\mathrm{R}} 31-32 \mathrm{~min}, 0.004 \%\right.$ dry wt). The $\mathrm{MeOH} / \mathrm{H}_{2} \mathrm{O}$ extract (1:1, $313.2 \mathrm{mg})$ was partitioned between $\mathrm{H}_{2} \mathrm{O}$ and $n$ - $\mathrm{BuOH}$. The $n$-BuOH-soluble material (33.6 
$\mathrm{mg}$ ) was fractionated using the same protocol described for the $n$-BuOH-soluble material, with $0.01 \%$ TFA added, and further quantities of comatulin A $\left(1,1.5 \mathrm{mg}, t_{\mathrm{R}} 72-74 \mathrm{~min}, 0.008 \%\right.$ dry wt) and $\mathrm{B}\left(2,1.1 \mathrm{mg}, t_{\mathrm{R}} 85-86 \mathrm{~min}, 0.006 \%\right.$ dry wt) were obtained.

The $\mathrm{CH}_{2} \mathrm{Cl}_{2}$ extract (354.3 $\mathrm{mg}$ ) of C. rotalaria (SBD522143) was subjected to the same diolbonded silica flash column chromatography conditions described for SBD517512. The fractions collected were combined following TLC analysis, yielding 10 fractions (F1-10). F8 contained 6methoxycomaparvin 5-methyl ether $\left(\mathbf{1 5}, 5.0 \mathrm{mg}, t_{\mathrm{R}} 44 \mathrm{~min}, 0.025 \%\right.$ dry wt). F5 was further purified by diol HPLC with a linear gradient from $5 \% i$-PrOH/95\% $n$-hexane to $12 \% i$-PrOH/ $88 \%$ $n$-hexane over $80 \mathrm{~min}$ to afford 6-methoxycomaparvin $\left(\mathbf{1 4}, 1.6 \mathrm{mg}, t_{\mathrm{R}} 32 \mathrm{~min}, 0.008 \%\right.$ dry wt) and 5,8-dihydroxy-6,10-dimethoxy-2-methyl-4H-benzo[h]chromen-4-one (16, $0.7 \mathrm{mg}, t_{\mathrm{R}} 45-46 \mathrm{~min}$, $0.004 \%$ dry wt). The red $\mathrm{MeOH}$ extract (1.02 g) was resuspended in $\mathrm{H}_{2} \mathrm{O}$ and partitioned sequentially into EtOAc, then $n$ - $\mathrm{BuOH}$. The $n$ - $\mathrm{BuOH}$ fraction-soluble material (244.0 mg) was fractionated using $\mathrm{C}_{18}$ Betasil HPLC column. Isocratic conditions of $10 \% \mathrm{MeOH} / 90 \% \mathrm{H}_{2} \mathrm{O}$ were held for $15 \mathrm{~min}$, followed by a linear gradient of $80 \% \mathrm{MeOH} / 20 \% \mathrm{H}_{2} \mathrm{O}(0.1 \% \mathrm{TFA})$ over $95 \mathrm{~min}$, then a linear gradient to $100 \% \mathrm{MeOH}$, and held at this condition $(0.1 \% \mathrm{TFA})$ for $10 \mathrm{~min}$, all at a flow rate of $9 \mathrm{~mL} / \mathrm{min}$. Fractions $69-70$ and 80-83 contained comatulins A (1, $1.6 \mathrm{mg}, 0.008 \%$ dry wt) and B (2, $5.8 \mathrm{mg}, 0.029 \%$ dry wt), respectively. Fractions $75-77$ (2.7 mg) were combined and further purified a using phenyl-hexyl HPLC column with isocratic condition of $60 \%$ $\mathrm{MeOH} / 40 \% \mathrm{H}_{2} \mathrm{O}(0.1 \% \mathrm{TFA})$ for $40 \mathrm{~min}$ to furnish comatulin E (5, $1.0 \mathrm{mg}, t_{\mathrm{R}} 30-31 \mathrm{~min} .0 .005 \%$ dry wt). The $\mathrm{MeOH} / \mathrm{H}_{2} \mathrm{O}$ extract $(1: 1,344.0 \mathrm{mg})$ was subjected to $\mathrm{C}_{18}$ Betasil HPLC using a linear gradient from $5 \% \mathrm{MeOH} / 95 \% \mathrm{H}_{2} \mathrm{O}(0.1 \% \mathrm{TFA})$ to $10 \% \mathrm{MeOH} / 90 \% \mathrm{H}_{2} \mathrm{O}(0.1 \% \mathrm{TFA})$ for $10 \mathrm{~min}$; this was then held at these isocratic conditions for $15 \mathrm{~min}$, followed by a linear gradient to $80 \%$ $\mathrm{MeOH} / 20 \% \mathrm{H}_{2} \mathrm{O}(0.1 \%$ TFA) over $105 \mathrm{~min}$, and a final linear gradient to $100 \% \mathrm{MeOH}(0.1 \%$ 
TFA) over $10 \mathrm{~min}$. Further quantities of comatulin B (2, $1.2 \mathrm{mg}, t_{\mathrm{R}} 80-81 \mathrm{~min}, 0.006 \%$ dry wt) and $\mathrm{E}\left(\mathbf{5}, 0.5 \mathrm{mg}, t_{\mathrm{R}} 76-77 \mathrm{~min}, 0.003 \%\right.$ dry $\left.\mathrm{wt}\right)$ were obtained.

Comatulin A (1): red amorphous powder; UV (MeOH) $\lambda_{\max }(\log \varepsilon) 222$ (3.92), 260 (3.76), 316 (3.91), 513 (3.41) nm; IR (UATR) $v_{\max } 3452,2981,1684,1623,1383,1207,1139,1055,802,726$ $\mathrm{cm}^{-1} ;{ }^{1} \mathrm{H}$ and ${ }^{13} \mathrm{C}$ NMR data, Tables 1 and 2; LRESIMS $\mathrm{m} / \mathrm{z} 464[\mathrm{M}-\mathrm{H}]^{-}$; HRESIMS $\mathrm{m} / z$ $464.0643[\mathrm{M}-\mathrm{H}]^{-}$(calcd for $\mathrm{C}_{20} \mathrm{H}_{18} \mathrm{NO}_{10} \mathrm{~S}, 464.0657$ ), $339.0499\left[\mathrm{M}-\mathrm{C}_{2} \mathrm{H}_{7} \mathrm{NO}_{3} \mathrm{~S}\right]^{-}$(calcd for $\left.\mathrm{C}_{18} \mathrm{H}_{11} \mathrm{O}_{7}, 339.0510\right)$.

Comatulin B (2): red amorphous powder; UV (MeOH) $\lambda_{\max }(\log \varepsilon) 223$ (3.57), 260 (3.41), 316 (3.57), $505(3.03) \mathrm{nm}$; IR (UATR) $v_{\max } 3708,2938,1603,1384,1033,844 \mathrm{~cm}^{-1} ;{ }^{1} \mathrm{H}$ and ${ }^{13} \mathrm{C}$ NMR data, Tables 1 and 2; LRESIMS m/z 492 [M - H] ${ }^{-}$; HRESIMS m/z $492.0947[\mathrm{M}-\mathrm{H}]^{-}$(calcd for $^{-}$ $\left.\mathrm{C}_{22} \mathrm{H}_{22} \mathrm{NO}_{10} \mathrm{~S}, 492.0970\right), 367.0806\left[\mathrm{M}-\mathrm{C}_{2} \mathrm{H}_{7} \mathrm{NO}_{3} \mathrm{~S}^{-}\right.$(calcd for $\mathrm{C}_{20} \mathrm{H}_{15} \mathrm{O}_{7}, 367.0823$ ).

Comatulin C (3): red amorphous powder; UV (MeOH) $\lambda_{\max }(\log \varepsilon) 221$ (3.53), 260 (3.32), 314 (3.53), 510 (2.95) nm; IR (UATR) $v_{\max } 3425,2981,1683,1626,1396,1207,1185,1137,802,725$ $\mathrm{cm}^{-1} ;{ }^{1} \mathrm{H}$ and ${ }^{13} \mathrm{C}$ NMR data, Tables 1 and 2; LRESIMS $\mathrm{m} / \mathrm{z} 450[\mathrm{M}-\mathrm{H}]^{-}$; HRESIMS $\mathrm{m} / \mathrm{z}$ $450.0492[\mathrm{M}-\mathrm{H}]^{-}$(calcd $\mathrm{C}_{19} \mathrm{H}_{16} \mathrm{NO}_{10} \mathrm{~S}$ for 450.0500), $325.0347\left[\mathrm{M}-\mathrm{C}_{2} \mathrm{H}_{7} \mathrm{NO}_{3} \mathrm{~S}\right]^{-}$(calcd for $\left.\mathrm{C}_{17} \mathrm{H}_{9} \mathrm{O}_{7}, 325.0354\right)$.

Comatulin D (4): red amorphous powder; UV (MeOH) $\lambda_{\max }(\log \varepsilon) 222$ (3.57), 261 (3.36), 314 (3.56), 505 (2.98) nm; IR (UATR) $v_{\max }$ 3426, 2981, 1683, 1623, 1388, 1207, 1139, 1055, 802, 726 $\mathrm{cm}^{-1} ;{ }^{1} \mathrm{H}$ and ${ }^{13} \mathrm{C}$ NMR data, Tables 1 and 2; LRESIMS $\mathrm{m} / \mathrm{z} 478[\mathrm{M}-\mathrm{H}]^{-}$; HRESIMS $\mathrm{m} / \mathrm{z}$ $478.0811[\mathrm{M}-\mathrm{H}]^{-}\left(\text {calcd } \mathrm{C}_{21} \mathrm{H}_{20} \mathrm{NO}_{10} \mathrm{~S} \text { for 478.0813), } \mathrm{m} / z \text { 353.0665 [M }-\mathrm{C}_{2} \mathrm{H}_{7} \mathrm{NO}_{3} \mathrm{~S}\right]^{-}$(calcd for $\left.\mathrm{C}_{19} \mathrm{H}_{13} \mathrm{O}_{7}, 353.0667\right)$.

Comatulin E (5): red amorphous powder; UV (MeOH) $\lambda_{\max }(\log \varepsilon) 259$ (3.19), $316(3.31), 517$ (2.82) nm; IR (UATR) $v_{\max } 3426,2981,1682,1439,1206,1137,1033,802,725 \mathrm{~cm}^{-1} ;{ }^{1} \mathrm{H}$ and ${ }^{13} \mathrm{C}$ 
NMR data, Tables 1 and 2; LRESIMS m/z $522[\mathrm{M}-\mathrm{H}]^{-}$; HRESIMS m/z $522.1074\left[\mathrm{M}-\mathrm{H}^{-}\right.$ (calcd $\mathrm{C}_{23} \mathrm{H}_{24} \mathrm{NO}_{11} \mathrm{~S}$ for 522.1076), $397.0929\left[\mathrm{M}-\mathrm{C}_{2} \mathrm{H}_{7} \mathrm{NO}_{3} \mathrm{~S}\right]^{-}$(calcd for $\mathrm{C}_{21} \mathrm{H}_{17} \mathrm{O}_{8}, 397.0929$ ). Rhodocomatulin 5,7-dimethyl ether (8): orange micro crystal, mp 178-180 ${ }^{\circ} \mathrm{C}$, (lit. ${ }^{12} 208.5-209$ $\left.{ }^{\circ} \mathrm{C}\right)$. LRESIMS $m / \mathrm{z} 369[\mathrm{M}-\mathrm{H}]^{-}$.

Rhodocomatulin (10): orange amorphous powder; ${ }^{1} \mathrm{H}$ NMR (DMSO- $d_{6}+$ trace TFA, $\left.800 \mathrm{MHz}\right)$ $\delta_{\mathrm{H}} 6.68(1 \mathrm{H}, \mathrm{s}, \mathrm{H}-3), 6.60(1 \mathrm{H}, \mathrm{d}, J=2.4 \mathrm{~Hz}, \mathrm{H}-6), 7.04(1 \mathrm{H}, \mathrm{d}, J=2.4 \mathrm{~Hz}, \mathrm{H}-8), 11.62(1 \mathrm{H}, \mathrm{br}$ s, OH-2), 12.44 (1H, s, OH-4), 12.10 (1H, s, OH-5), 11.35 (1H, br s, OH-7), 2.62 (2H, br s, H-2'), $1.68\left(2 \mathrm{H}, \mathrm{qt}, J=7.6,7.6 \mathrm{~Hz}, \mathrm{H}-3^{\prime}\right), 0.97\left(3 \mathrm{H}, \mathrm{t}, J=7.6 \mathrm{~Hz}, \mathrm{H}-4{ }^{\prime}\right) ;{ }^{13} \mathrm{C}$ NMR (DMSO- $d_{6}+$ trace TFA, $200 \mathrm{MHz}) \delta_{\mathrm{C}} 126.5(\mathrm{C}, \mathrm{C}-1), 161.2(\mathrm{C}, \mathrm{C}-2), 108.2(\mathrm{CH}, \mathrm{C}-3), 163.7$ (C, C-4), $108.2(\mathrm{C}, \mathrm{C}-$ 4a), 164.1 (C, C-5), 108.3 (CH, C-6), 165.2 (C, C-7), 108.8 (CH, C-8), 134.6 ${ }^{a}$ (C, C-8a), 181.9 (C, C-9), $131.1^{a}$ (C, C-9a), 188.8 (C, C-10), 108.6 (C, C-10a), $203.2\left(\mathrm{C}, \mathrm{C}-1^{\prime}\right), 44.4\left(\mathrm{CH}_{2}, \mathrm{C}-2^{\prime}\right), 16.5$ $\left(\mathrm{CH}_{2}, \mathrm{C}-3^{\prime}\right), 13.5\left(\mathrm{CH}_{3}, \mathrm{C}-4{ }^{\prime}\right)$; LRESIMS m/z $341[\mathrm{M}-\mathrm{H}]^{-} ; \operatorname{HRESIMS~m/z~341.0663~[M~-~H]~}$

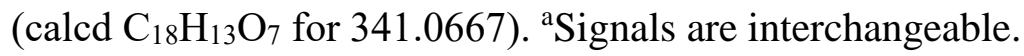

6-Methoxyrhodocomatulin 7-methyl ether (12): orange amorphous powder; ${ }^{1} \mathrm{H}$ NMR (DMSO$d_{6}+$ trace TFA, $\left.800 \mathrm{MHz}\right) \delta_{\mathrm{H}} 6.69(1 \mathrm{H}, \mathrm{s}, \mathrm{H}-3), 7.31(1 \mathrm{H}, \mathrm{s}, \mathrm{H}-8), 11.77(1 \mathrm{H}, \mathrm{br} \mathrm{s}, \mathrm{OH}-2), 12.28$ (1H, s, OH-4), 12.11 (1H, s, OH-5), 3.84 (3H, s, H-6), 3.98 (3H, s, H-7), 2.69 (2H, br s, H-2'), 1.69 $\left(2 \mathrm{H}\right.$, br qt, $\left.J=7.5,7.5 \mathrm{~Hz}, \mathrm{H}-3^{\prime}\right), 0.97\left(3 \mathrm{H}, \mathrm{t}, J=7.5 \mathrm{~Hz}, \mathrm{H}-4{ }^{\prime}\right) ;{ }^{13} \mathrm{C}$ NMR (DMSO- $d_{6}+$ trace TFA, $200 \mathrm{MHz}) \delta_{\mathrm{C}} 126.7$ (C, C-1), 161.7 (C, C-2), 108.0 (CH, C-3), 163.7 (C, C-4), 108.3 (C, C-4a), 155.3 (C, C-5), 141.3 (CH, C-6), 60.4 ( $\left.\mathrm{CH}_{3}, \mathrm{OMe}-6\right), 158.0$ (C, C-7), $56.5\left(\mathrm{CH}_{3}, \mathrm{OMe}-7\right), 104.6$ (CH, C-8), 128.4 (C, C-8a), 181.2 (C, C-9), 131.0 (C, C-9a), 189.5 (C, C-10), 111.1 (C, C-10a), 203.2 (C, C-1'), $44.5\left(\mathrm{CH}_{2}, \mathrm{C}-2^{\prime}\right), 16.4\left(\mathrm{CH}_{2}, \mathrm{C}-3^{\prime}\right), 13.6\left(\mathrm{CH}_{3}, \mathrm{C}-4^{\prime}\right)$; LRESIMS m/z 385 [M - H] ${ }^{-}$; HRESIMS $m / z$ 385.0922 [M - H] $]^{-}\left(\right.$calcd $\mathrm{C}_{20} \mathrm{H}_{17} \mathrm{O}_{8}$ for 385.0929). 
Methylation of 6-Methoxycomaparvin 5-methyl ether (15). Compound 15 (3.2 mg, 0.0093 mmol) was dissolved in $1 \mathrm{~mL}$ of anhydrous $\mathrm{CH}_{2} \mathrm{Cl}_{2}: \mathrm{MeOH}(1: 1)$ and TMS-diazomethane (125 $\mu \mathrm{L}$, $0.786 \mathrm{mmol}$ ) was added dropwise. ${ }^{24}$ The reaction was stirred for $12 \mathrm{~h}$ at room temperature. The reaction mixture was dried and purified using a $\mathrm{C}_{18}$ Luna HPLC column with a linear gradient from $60 \% \mathrm{MeOH} / 40 \% \mathrm{H}_{2} \mathrm{O}$ to $100 \% \mathrm{MeOH}$ over $60 \mathrm{~min}$ at a flow rate of $4 \mathrm{~mL} / \mathrm{min}$. The methylated product, 6-methoxycomaparvin 5,8-dimethyl ether (17, $\left.2.4 \mathrm{mg}, t_{\mathrm{R}} 31-33,73.5 \%\right)$ eluted at fractions 31-33.

6-Methoxycomaparvin 5,8-dimethyl ether (17): pale yellow amorphous powder, ${ }^{1} \mathrm{H}$ NMR $\left(\mathrm{CDCl}_{3}, 800 \mathrm{MHz}\right) \delta_{\mathrm{H}} 6.21(1 \mathrm{H}, \mathrm{s}, \mathrm{H}-3), 7.12(1 \mathrm{H}, \mathrm{d}, J=2.3 \mathrm{~Hz}, \mathrm{H}-7), 6.59(1 \mathrm{H}, \mathrm{d}, J=2.3 \mathrm{~Hz}, \mathrm{H}-$ 9), $2.65(2 \mathrm{H}, \mathrm{t}, J=7.4 \mathrm{~Hz}, \mathrm{H}-11), 1.87$ (2H, qt, $J=7.4,7.4 \mathrm{~Hz}, \mathrm{H}-12), 1.04(3 \mathrm{H}, \mathrm{t}, J=7.4 \mathrm{~Hz}, \mathrm{H}-$ 13), 3.97 (3H, s, H-5), 4.04 (3H, s, H-6), 3.97 (3H, s, H-8), 3.98 (3H, s, H-10); ${ }^{13} \mathrm{C} \mathrm{NMR} \mathrm{(} \mathrm{CDCl}_{3}$, $200 \mathrm{MHz}) \delta_{\mathrm{C}} 166.6$ (C, C-2), 111.9 (CH, C-3), 177.8 (C, C-4), 115.0 (C, C-4a), 147.1 (C, C-5), 143.8 (C, C-6), 135.0 (C, C-6a), 93.2 (CH, C-7), 161.4 (C, C-8), 99.4 (CH, C-9), 159.4 (C, C-10), 108.9 (C, C-10a), 153.3 (C, 10b), $36.0\left(\mathrm{CH}_{2}, \mathrm{C}-11\right), 19.9\left(\mathrm{CH}_{2}, \mathrm{C}-12\right), 13.7\left(\mathrm{CH}_{3}, \mathrm{C}-13\right), 61.9$ ( $\left.\mathrm{CH}_{3}, \mathrm{OMe}-5\right), 61.4\left(\mathrm{CH}_{3}, \mathrm{OMe}-6\right), 55.7\left(\mathrm{CH}_{3}, \mathrm{OMe}-8\right), 56.2\left(\mathrm{CH}_{3}, \mathrm{OMe}-10\right)$; LRESIMS m/z 359 $[\mathrm{M}+\mathrm{H}]^{+} ;$HRESIMS m/z $359.1486[\mathrm{M}+\mathrm{H}]^{+}\left(\right.$calcd $_{20} \mathrm{H}_{23} \mathrm{O}_{6}$ for 359.1489$)$.

X-ray Crystallography Analysis. Intensity data for rhodocomatulin 5,7-dimethyl ether (8) was collected with an Oxford Diffraction Synergy diffractometer using $\mathrm{Cu}-\mathrm{K} \alpha$ radiation, the temperature during data collection was maintained at 100.0(1) K using an Oxford Cryosystems cooling device. The structure was solved by direct methods and difference Fourier Synthesis. ${ }^{25}$ Hydrogen atoms bound to the carbon atom were placed at their idealized positions using appropriate HFIX instructions in SHELXL, and included in subsequent refinement cycles. The 
hydrogen atom attached to oxygen was located from difference Fourier maps and refined freely with isotropic displacement parameters. Thermal ellipsoid plots were generated using the program ORTEP- $3^{26}$ integrated within the WINGX suite of programs. ${ }^{27}$ Crystallographic data for compound 8 (CCDC No 1969864) have been deposited with the Cambridge Crystallographic Data Centre. These data can be obtained free of charge from the Cambridge Crystallographic Data Centre via http://www.ccdc.cam.ac.uk/data request/cif.

Crystal Data for Rhodocomatulin 5,7-dimethyl ether (8). $\mathrm{C}_{20} \mathrm{H}_{18} \mathrm{O}_{7} \cdot \mathrm{H}_{2} \mathrm{O}, M=388.36, T=$ 100.0(10) $\mathrm{K}, \lambda=1.54184 \AA$, Monoclinic, space group P 21/c $a=9.2710(2), b=9.6883(3), c=$ 19.4904(4) $\AA, V=1749.46(8) \AA^{3}, Z=4, D_{c}=1.474 \mathrm{Mg} \mathrm{M}^{-3} \mu=0.970 \mathrm{~mm}^{-1}, F(000)=816$, crystal size $0.355 \times 0.235 \times 0.025 \mathrm{~mm}^{3} . \theta_{\max }=77.19^{\circ}, 20845$ reflections measured, 3675 independent reflections $\left(\mathrm{R}_{\text {int }}=0.0723\right)$ the final $\mathrm{R}=0.0827\left[\mathrm{I}>2 \sigma(\mathrm{I}), 3281\right.$ data] and $w \mathrm{R}\left(\mathrm{F}^{2}\right)=0.2628$ (all data) $\mathrm{GOOF}=1.262$.

HIV-1 Replication and Apoptosis Assays. HIV-1 replication assays were performed as described previously ${ }^{19}$. Compounds were assessed in at least two independent experiments at 100, $30,10,3$ and $1 \mu \mathrm{M}$. The antiretroviral individir was used as a positive control, where it inhibited $72 \pm 4 \%$ of HIV replication at $0.1 \mu \mathrm{M}$.

Anthelmintic Assays. The compounds were tested in established Haemonchus contortus assays $^{28}$ using a two-fold dilution series, starting at $100 \mu \mathrm{M}(+0.25 \% \mathrm{DMSO})$, for their inhibitory effect on xL3 motility at $72 \mathrm{~h}$ and L4 development at seven days. For all experiments, monepantel and moxidectin (reference compounds) were tested in the same concentration range, while culture medium with $0.25 \%$ DMSO served as a negative control. All motility and development assays, with three technical replicates in each assay, were repeated three times. For individual compounds, the half-maximum inhibitory concentration $\left(\mathrm{IC}_{50}\right)$ values were determined by transforming the 
concentration to $\log 10$ and fitting to a variable slope four-parameter model using GraphPad software (version 8.3.1).

\section{ASSOCIATED CONTENT}

\section{Supporting Information}

The Supporting Information is available free of charge on the ACS Publications website at DOI: 10.1021/acs.jnatprod.

UHPLC-MS data, tabulated NMR data and 1D/2D NMR spectra of comatulins A-E. (PDF)

\section{AUTHOR INFORMATION}

\section{Corresponding Author}

* Tel: +61-7-3735-6043. Fax: +61-7-3735-6001. E-mail: r.davis@ griffith.edu.au

\section{Notes}

The authors declare no competing financial interest.

\section{ACKNOWLEDGMENTS}

The authors acknowledge the Australian Research Council (ARC) for support towards NMR and MS equipment (grants LE0668477, LE140100119, and LE0237908). R.B.G's research is currently supported by the ARC, Yourgene Health and Melbourne Water Corporation. The HIV screening was supported by the Canadian Institutes for Health Research (CIHR PJT-153057) (I.T.), the New Frontiers in Research Fund - Explorations (NRFRE-2018-01386) (I.T.) and a Griffith UniversitySimon Fraser University Collaborative Travel Grant (I.T., R.A.D.). We gratefully acknowledge 
the Australian Institute for Marine Science (AIMS) for supply of the two crinoid samples reported in this study. These samples are part of the AIMS Bioresources Library which has recently been added to the NatureBank biota repository, where they are available for biodiscovery research. We also thank M. Bryant from the Queensland Museum for curation of the crinoid sample. K.Y.L. would like to acknowledge Griffith University for the PhD scholarships (GUIPRS and GUPRS). 


\section{REFERENCES}

(1) Feng, Y.; Khokhar, S.; Davis, R. A., Nat. Prod. Rep. 2017, 34, 571-584.

(2) Takahashi, D.; Maoka, T.; Tsushima, M.; Fujitani, K.; Kozuka, M.; Matsuno, T.; Shingu, T., Chem. Pharm. Bull. 2002, 50, 1609-1612.

(3) Rideout, J. A.; Smith, N. B.; Sutherland, M. D., Experientia 1979, 35, 1273-1274.

(4) De Riccardis, F.; Iorizzi, M.; Minale, L.; Riccio, R.; Richer de Forges, B.; Debitus, C., J. Org. Chem. 1991, 56, 6781-6787.

(5) Laille, M.; Gerald, F.; Debitus, C., Cell. Mol. Life. Sci. 1998, 54, 167-170.

(6) Tseng, C. C.; Lai, Y. C.; Kuo, T. J.; Su, J. H.; Sung, P. J.; Feng, C. W.; Lin, Y. Y.; Chen, P. C.; Tai, M. H.; Cheng, S. Y.; Kuo, H. M.; Wen, Z. H., Mar. Drugs 2019, 17, 138.

(7) Lum, K. Y.; Carroll, A. R.; Ekins, M. G.; Read, S.; Haq, Z.; Tietjen, I.; St John, J.; Davis, R. A., Mar. Drugs 2019, 17, 26.

(8) Francesconi, K. A., Aust. J. Chem. 1980, 33, 2781-2784.

(9) Khokhar, S.; Pierens, G. K.; Hooper, J. N.; Ekins, M. G.; Feng, Y.; Davis, R. A., J. Nat. Prod. 2016, 79, 946-953.

(10) NatureBank, Griffith Institute for Drug Discovery. https://www.griffith.edu.au/institute-drugdiscovery/unique-resources/naturebank (accessed 12 January, 2020),

(11) Sutherland, M. D.; Wells, J. W., Chem. Ind. 1959, 291-292.

(12) Sutherland, M. D.; Wells, J. W., Aust. J. Chem. 1967, 20, 515-533.

(13) Folmer, F.; Harrison, W. T.; Tabudravu, J. N.; Jaspars, M.; Aalbersberg, W.; Feussner, K.; Wright, A. D.; Dicato, M.; Diederich, M., J. Nat. Prod. 2008, 71, 106-111.

(14) Bokesch, H. R.; Cartner, L. K.; Fuller, R. W.; Wilson, J. A.; Henrich, C. J.; Kelley, J. A.; Gustafson, K. R.; McMahon, J. B.; McKee, T. C., Bioorg. Med. Chem. Lett. 2010, 20, 3848-3850.

(15) Wolkenstein, K.; Fuentes-Monteverde, J. C.; Nath, N.; Oji, T.; Griesinger, C., J. Nat. Prod. 2019, 82, 163-167.

(16) Schinazi, R. F.; Chu, C. K.; Babu, J. R.; Oswald, B. J.; Saalmann, V.; Cannon, D. L.; Eriksson, B. F. H.; Nasr, M., Antiviral Res. 1990, 13, 265-272.

(17) Esposito, F.; Corona, A.; Zinzula, L.; Kharlamova, T.; Tramontano, E., Chemotherapy 2012, 58, 299-307.

(18) Rideout, J. A.; Smith, I. R.; Sutherland, M. D., Aust. J. Chem. 1976, 29, 1087-1098. 
(19) Tietjen, I.; Ntie-Kang, F.; Mwimanzi, P.; Onguene, P. A.; Scull, M. A.; Idowu, T. O.; Ogundaini, A. O.; Meva'a, L. M.; Abegaz, B. M.; Rice, C. M.; Andrae-Marobela, K.; Brockman, M. A.; Brumme, Z. L.; Fedida, D., PLoS One 2015, 10, e0121099.

(20) Geary, T. G., Chapter Ten - Haemonchus contortus: Applications in Drug Discovery. In Advances in Parasitology, Gasser, R. B.; Samson-Himmelstjerna, G. V., Eds. Academic Press: 2016; Vol. 93, pp 429-463.

(21) Jiao, Y.; Preston, S.; Garcia-Bustos, J. F.; Baell, J. B.; Ventura, S.; Le, T.; McNamara, N.; Nguyen, N.; Botteon, A.; Skinner, C.; Danne, J.; Ellis, S.; Koehler, A. V.; Wang, T.; Chang, B. C. H.; Hofmann, A.; Jabbar, A.; Gasser, R. B., Int J Parasitol Drugs Drug Resist 2019, 9, 59-71.

(22) ChemDraw Ultra 12.0.02.1076. https://www.perkinelmer.com/category/chemdraw

(23) Rideout, J. A.; Sutherland, M. D., Aust. J. Chem. 1981, 34, 2385-2392.

(24) Barnes, E. C.; Kavanagh, A. M.; Ramu, S.; Blaskovich, M. A.; Cooper, M. A.; Davis, R. A., Phytochemistry 2013, 93, 162-169.

(25) Sheldrick, G., Acta Crystallogr. 2008, A64, 112-122.

(26) Farrugia, L., J. Appl. Crystallogr. 1997, 30, 565.

(27) Farrugia, L., J. Appl. Crystallogr. 1999, 32, 837-838.

(28) Preston, S.; Jabbar, A.; Nowell, C.; Joachim, A.; Ruttkowski, B.; Baell, J.; Cardno, T.; Korhonen, P. K.; Piedrafita, D.; Ansell, B. R. E.; Jex, A. R.; Hofmann, A.; Gasser, R. B., Int. J. Parasitol. 2015, 45, 333-343. 
Table of Content Graphic

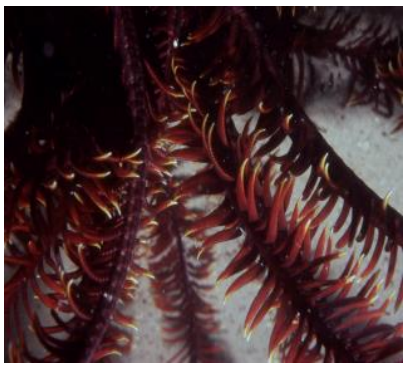

Comatula rotalaria

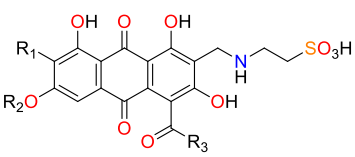

$\mathrm{R}_{1}=\mathrm{H}, \mathrm{R}_{2}=\mathrm{Me}, \mathrm{R}_{3}=\mathrm{Me}$

$R_{1}=H, R_{2}=M e, R_{3}=P r$

$R_{1}=R_{2}=H, R_{3}=M e$

$R_{1}=R_{2}=H, R_{3}=P r$

$R_{1}=O M e, R_{2}=M e, R_{3}=P r$

Comatulins A-E 